\title{
Strategies Used by Professors through Virtual Educational Platforms in Face-To-Face Classes: A View from the Chamilo Platform
}

\author{
Heriberto Gonzalez Valencia ${ }^{1}$, Jackeline Amparo Villota Enriquez ${ }^{1} \&$ Patricia Medina Agredo $^{1}$ \\ ${ }^{1}$ Education Faculty, Santiago de Cali University, Cali, Valle, Colombia \\ Correspondence: Heriberto Gonzalez Valencia, Education Faculty, Santiago de Cali University, Cali, Valle, \\ Colombia. Tel: 57-313-720-7896. E-mail: hery77@hotmail.com
}

Received: May 26, 2017 Accepted: July 1, 2017 Online Published: July 3, 2017

doi: 10.5539/elt.v10n8p1 URL: http://doi.org/10.5539/elt.v10n8p1

\begin{abstract}
This study consisted in characterizing the strategies used by professors; implemented through virtual educational platforms. The context of this research were the classrooms of the Santiago de Cali University and the virtual space of the Chamilo virtual platform, where two professors from the Faculty of Education of the same university participated. The methodological approach of the investigation is qualitative, the observation and the interviews were the procedure to collect the data used. The results obtained and the analyzed literature show that there are different strategies used by professors through the implementation of the Chamilo virtual educational platform as a support to face-to-face classes, leading us to recognize that its utility has different intentions at the moment of being implemented by the professor.
\end{abstract}

Keywords: teaching strategies, virtual educational platforms, professors' training

\section{Introduction}

In today's globalized world, technology is part of the daily activities for many people, and students are a population that maintains permanent contact with it. The integration of different and varied forms of technological tools in academia allows teaching and learning processes to become a meaningful experience for students in any field. Virtual education platforms have become a high-quality complement to educational processes, integrating them academically allows obtaining significant achievements and increases motivation.

The integration of virtual education platforms offer an unlimited number of tools, which can be used at any time and space where you have a computer and an online connection. This allows both synchronous and asynchronous interaction and permanent communication between student-professor and student-student. All this resulting in a very effective collaborative work.

In this way, in particular, the virtual platform Chamilo of the Santiago de Cali University is a didactic tool for the academic community and all the areas of its faculties designed to enhance the teaching and learning processes. It is an environment conceived as a space for authentic content, synchronous and asynchronous tutoring, projects, and participation in forums for discussion, among others, which leads us to observe the strategies that professors use through a particular virtual educational platform.

The relationship between teaching strategies and the use of virtual platforms leads us to recognize that there are different elements that strengthen the pedagogical practice of the professor by expanding the range of strategies used in face-to-face classes; that is, integrating tools such as virtual educational platforms into the learning process of the student.

Currently, in the Valle del Cauca region (Colombia), many universities have virtual platforms, which are designed to provide greater quality in education and allow academic flexibility for both students and professors, integrating ICT in the pedagogical practice of the professor, inviting him/her to experiment with elements that help strengthen the teaching and learning process.

It is important to think of an innovative process in terms of the integration of virtual platforms in all teaching and learning spaces, with flexible education schemes, adjusted to the reality of the social environment and used by the entire academic community.

According to what is mentioned above, this study consisted of characterizing the strategies used by professors of 
the Faculty of Education of the Santiago de Cali University, through the virtual educational platform "Chamilo". Initially, the strategies will be identified and later described.

\subsection{Educational Virtual Platforms}

In a globalized world, the use of technology is an essential part of current development; without losing sight of the fact that it has always accompanied the human being from antiquity to our times. There are a number of different examples, where humans have used technology, among them: the use of a stone, learning to ignite fire, the detonation of the atomic bomb, among others, where it is visualized that technology has always persuaded our daily living.

Given the correspondence that technology has had with the daily life of the human being; it is important to emphasize that it is also related to different fields and / or fields, including education; which has undoubtedly made a presence in the pedagogical practice of the professor in order to strengthen the teaching and learning process.

Education finds in technology one of the best tools for optimizing its teaching and learning processes. Thus, when integrating technologies in education, aspects such as the strategies used in classes, the dispositions of educational institutions, inter-institutional work and the economic resources of the community, among others, must be taken into account. The student must be prepared to have autonomy and capacity in order to be able to handle the technology that is within his reach, Pavon (2005).

Currently, there are different didactic tools related to technology such as; virtual educational platforms, which can be used by the professor within his pedagogical practice in order to promote better learning in the student. The virtual educational platforms are fundamental elements that help to strengthen the process of teaching and learning generating interest in the pedagogical practice of the professor.

In this study, we will define virtual platforms as a didactic offer for the academic community in all areas, designed to enhance teaching and learning processes; That is to say, an environment conceived as a space for authentic content, synchronous and asynchronous tutoring, projects, and participation in forums for discussion, among others. In other words, virtual educational platforms are didactic elements that try to enrich the process of teaching and learning.

Many universities worldwide are integrating virtual platforms in the purpose of blended learning (B-learning) as a system of improvement in the quality of their teaching and learning processes; something that urges professors, from the institutional guidelines, to the creation of courses in their virtual platform, as a support to face-to-face classes. For years we have been combining lecture classes with exercises, case studies, role plays, and video and audio recordings, not to mention counseling and mentoring (Brodsky, 2003).

Particularly, in the Valle del Cauca region, many universities have virtual platforms, which are intended to provide higher quality education and allow academic flexibility for both students and professors. At the national level, the virtual platforms are framed in the educational policy guidelines of the Ministry of National Education (MEN, 2006); so it is necessary to use it in the professor's pedagogical practice.

In relation to the above, Ardilla (2011) states that Colombian universities must break their organizational complexity and cultural barriers so that directives and professors do not perceive technologies as intrusive, but rather as elements that can help strengthen the teaching and learning process. That is to say, the technologies as in this particular case, the virtual platforms, are elements integrated to the different academic processes of the university in order to promote the learning process of the student.

Thus, the integration of virtual platforms into academic processes provides the opportunity to increase academic achievement in the pedagogical practice of the professor and it eliminates many barriers of time and space. In addition, the integration of virtual educational platforms into the pedagogical practice of the professor allows the interaction with technological tools, which are part of the daily life of the current world generating a significant value of technology as an academic tool in classes trying to be a determinant factor in the planning and development of classes, González (2015).

The implementations of virtual platforms in academic environments, in all universities around the world, are becoming increasingly evident in the search for improvements in teaching and learning processes. Consequently, Pincas (2003) justifies blended learning as a "soft" option for introducing information technologies in education; for example, by linking the different topics studied in face-to-face classes to the virtual educational platforms in order to achieve meaningful learning.

The use of a virtual platform provides students with academic flexibility, which makes learning processes more 
motivating, where in fact, many factors influence stimulus and disposition; as stated by Cebrían (1997, p. 2) "The great challenge of technological innovation is a change in the mentality of professors and their teaching practice; as well as in their permanent training according to the demands of the market."

On the other hand, an improvement in the integration of the platform with each of its face-to-face actors can substantially aid the enrichment of teaching and learning processes. It is pertinent to clarify between the use and the integration of a platform. Angeli and Valanides (2009) tells us that technology for instruction integration requires knowledge and skills that are different from simple computer use. The integration of the platform in the classroom can be evidenced when these are part of the whole process of teaching and learning that involves all participants.

Given the above, in this study we will unveil the importance of the strategies used by professors in their face-to-face courses through the Chamilo virtual platform. Initially, the strategies will be identified and described in order to show that the integration of the virtual platform is a didactic support in all the programs of the Faculty of Education of the Santiago de Cali University, in the face-to-face courses.

\subsection{Teaching Strategies through Virtual Platforms}

The concept of strategy is related to the military field where its greater development was treated in the war. The strategy is linked to the war which since the antiquity has made presence in our society until our present time as Villota \& Riascos (2017) argue:

The concept of strategy appears initially linked to the military and had a practical development since Alexander the Great (356-323 ac), passing through Hannibal (249-183 ac), Scipio the African (236-184 ac), Julio César (100- 44 BC), including Frederick the Great (1717-1786) and Napoleon (1769-1821), until Charles von Clausewitz (1780-1813) establishes it theoretically in his work "from the war", consisting of 8 books, defining it as "the art of the generals". In the nineteenth and twentieth centuries they have a late development as a scientific or methodological tool to solve the problems presented by politics in the face of national interests or national groups that shared common interests and opposed antagonistic groups (Santos Pico, 2004). At the beginning of the 21st century, in this military field, strategy is understood as a methodological resource that facilitates this task, especially in times of crisis, so it can be concluded that the concept of strategy, from this perspective, is nothing else that the art of overcoming the contrary.

Consequently, the concept of strategy in the educational field helps the development of educational research in different lines; that is to say, the strategy is an integral and transversal concept in the field of education, which, generates a great relationship with the student and professor in the moment of proposing and resolving teaching situations proposed to share knowledge through the themes addressed in the different curricula contents established by the Ministry of National Education.

Therefore, in this article, we will define teaching strategies as those orientations that the professor gives to students in order to promote learning; that is to say, it is the orientations that the professor provides to his students with the purpose of developing in them different capacities for the interpretation of the information related to a certain task. In this case in particular, teaching strategies refer to the set of orientations that the professor gives his students in order to promote different learning situations, Villota (2016).

In this way, the professor implements different teaching strategies during his pedagogical practice, through tools related to ICT, particularly virtual educational platforms, which are intended to strengthen the learning process of the students. Thus, the virtual educational platforms, although they are part of the ICT, are intended to be elements that support the pedagogical practice of the professor generating significant learning in the students.

In this sense, we recognize that teaching strategies have a strong relationship with virtual educational platforms, turning their use into a challenge that undoubtedly tries to strengthen the professional and academic trajectory of the professor. The usefulness of virtual educational platforms, particularly in face-to-face courses, becomes important as they help the students to conceptualize different topics addressed by the professor. (Fernández \& Bermúdez, 2009)

Consequently, the use of virtual platforms in the field of education is a global trend, which tries to help us strengthen the communication and interaction between professor and student, as stated by Diaz (2009, p. 2) "They are a computer environment in which we find many tools grouped and optimized for teaching purposes. Its function is to allow the creation and management of complete internet courses without the need for deep programming knowledge".

According to what is mentioned above, it is important to present some studies regarding teaching strategies through the implementation of virtual educational platforms. In the research carried out by Fernández and 
Bermúdez (2009), they take the virtual educational platform Moodle as a medium, in which the professors present the basic contents that the students must work with. The development of didactic contents in the platform facilitates the acquisition of the competences in the management of didactic aids, this means introducing the students in the virtual learning and integrating the ICT; generating different strategies by the professor, before, during, and after the implementation of the platform as: the selection of contents, their structuring, access to different resources in the platform, interaction with students, and collaborative work, among others.

The study proposed by Sánchez, García y Grosso (2014) present the virtual platform Moodle as a didactic tool to dynamize reading and writing in students. This platform is used in the classroom, where it aims to focus on the communicative processes between students and the professor through elements such as the forum and chat. In a synchronous and asynchronous way, thus strengthening reading and writing in students. These elements help students actively participate in discussions on a specific topic, making them more motivated to read, analyze and present their points of view through solid arguments that promote the dialogue of knowledge, critical thinking and social construction of knowledge.

Another study addressed by Bustillo, Rivera, Guzman, and Ramos (2017) shows how through the use of a particular mobile application, the professor uses different teaching strategies with the intention of generating meaningful learning for certain English themes. Among the strategies used by the professor, this research delineates the integration of the curriculum, the intrinsic motivation of the students to develop the different situations of teaching provided to the students, the use of authentic materials, among others.

The above mentioned studies show us the importance of implementing teaching strategies through the virtual platforms in the classroom, giving us the opportunity to use tools that help to promote meaningful learning in the students. Thus, Villota (2016) argues that teaching strategies beyond a meaningless recipe, are fundamental elements that enrich the pedagogical practice as long as the professor takes into account their objectives and intentionality at the time of being implemented with the students. It should be noted that we are teaching to subjects and not to objects.

Next, we present the context where this study and the methodology were developed. In this section, we will discuss information about the training and pedagogical practice of the professors participating in this research, related to the school context. As for the methodology, we will explain the instruments used for the production of the data.

\subsection{Context}

The data of this study were collected in each of the classrooms of the respective professors who belong to the Education Faculty. In addition, the population from which the information was obtained were the directives, professors and students of the Education Faculty of the University in the period 2016.

Thus, in this research in particular, the main participants were two professors from the faculty of Education of the Santiago de Cali University. It is important to emphasize that the professors within this study guided different courses in the programs. Basic Education with emphasis in Technology and Informatics and Foreign Languages.

\section{Research Methodology}

This is a descriptive research with a qualitative approach, according to Yuni and Urbano (2014) since the qualitative data analysis is a planned, systematic and progressive activity, this allowed the development of research in a very natural way. The teaching strategies used by professors using the Chamilo virtual platform as a didactic tool were characterized.

Qualitative research allows significant data to be obtained, from surveys, interviews, observation and follow-up. In this research the data collection was done by means of a follow-up to the active courses in the platform Chamilo of the university and more specifically of the Education Faculty. A filmed record of two interviews was also made to two professors of the faculty.

Important data was also obtained from a virtual survey which the professors answered, questions directed to the program directives and a forum answered by the students in the virtual platform.

Thus, the number of active courses in the virtual platform with their respective professors and students were recorded. It was also checked which of the courses had activity in the period of the research. Two users were created to follow the courses, one of the users was created as a student and the other as a tutor of the course. This allowed to see the course from two different points of view.

From this information, two of the active courses were followed up for a period of ten weeks, recording the activities (forums, exams, announcements, documents, tasks and chats) proposed by the professor as a support to 
his face-to-face classes.

It was inquired about the number of professors in the university's Education Faculty, among them two female professors were chosen for an interview about the integration of the platform as support for their face-to-face classes; the interviews, which lasted approximately thirty minutes, were recorded, and later transcribed for analysis.

The professors answered a survey about the integration of the virtual platform in their face-to-face classes and the knowledge of the platform which the university offers, in the Google Docs application to facilitate times and spaces.

In one of the final forums of each follow-up course, the professor was asked to discuss about the integration of the platform in the face-to-face classes with students, the overall appreciation was positive. Most of the students expressed that it was a very useful didactic tool in their learning processes.

\section{Data Presentation}

In this section, the situations that were presented were structured around the words and actions of 2 professors, which we will call professor 1 and professor 2, respectively; during the implementation of the Chamilo virtual platform in face-to-face courses. In addition to the words collected in the observation process, it was used as a query, to perform the different interviews to the professors.

Thus, some of the elements used in the transcription of the data are treated in the works of Brum-de-Paula and Espinar (2002). However, the others are adapted to support transcription. Among these elements we have several codes such as: 1) the information inside brackets that indicate an action of the participants or explanations of the way they speak. 2) The symbol "..." to show an idea or word.

In addition to these codes, each transcript line was enumerated from (1), precisely to facilitate localization when references are made to it. However, before each numbering, we assign a letter to identify at what point they are reported on the line, i.e. the letter $\mathrm{O}$ is assigned to the lines recorded during the observation of professors in the development of tasks. Thus, the first line of each episode of transcription begins with (O1); the second one by (O2); and so on.

The situations were constructed from what was considered important in the observation and expressed suggestively. In this article, in each situation, the strategies implemented by professor 1 and professor 2 can be evidenced and showed in a chronological order. Thus, each situation represents a teaching strategy where it was built; That is, we will have different situations, where each of them refers to the strategy used by each professor.

\section{Situation 1:}

In this situation we will present the teaching strategy called "Upload documents and links", which consisted of sharing different documents in PDF and Word format on readings related to the topics dealt with in the classroom, and additional links were also uploaded from websites.

\section{Moment of Implementation-Professor 1}

(O1) Professor 1: [Selects the readings of scientific articles and links referring to the didactics course of Informatics, then uploads them to the Chamilo virtual platform in PDF]

(O2) Professor 1: I share the documents on the history readings of computer science.

(O3) Student 1: OK!

(O4) Student 2: Are they to be discussed in class?

(O5) Professor 1: Yes, the idea is to read and debate in class.

\section{Moment of Implementation-Professor 2}

(O6) Professor 2: [Choose the documents and links regarding readings and workshops on English level 2 and then share it on the Chamilo virtual platform in Word]

(O7) Professor 2: Readings are on the platform, please read to discuss next Tuesday in class.

(O8) Student: [Send challenge emoticon]

It is observed that in the (O1) and (O6) each of the professors initially carried out a literature review on the 
topics to be treated in order to select the readings that they are going to share with the students in the Chamilo virtual platform and later discuss them in face-to-face classes. In $(\mathrm{O} 2)$ and $(\mathrm{O} 7)$ professors share the readings, they are uploaded in PDF and Word, generating in $(\mathrm{O} 3),(\mathrm{O} 4)$, and $(\mathrm{O} 8)$ motivational reactions in students.

Similarly, this happens when the professors share the links of the web pages referring to the different topics to be dealt with in the face-to-face classes.

\section{Situation 2}

In this situation we will present the teaching strategy called "Test implementation" which consisted in elaborating a certain examination based on the tools offered by the Chamilo platform, including multiple choice, short answers, matching, and open questions, among others. It is important to emphasize that this strategy was only used by the professor 1 .

\section{Moment of Implementation-Professor 1}

(O1) Professor 1: [After reviewing and explaining a specific topic in the classroom, the professor designs an exam with different types of questions, which students have to complete at any time, but with a set deadline.]

(O2) Professor 1: On the platform I shared the computer didactics exam to solve it until November $12^{\text {th }}$. Please take the exam.

(O3) Student 1: Is that the exam?

(O4) Student 2: Is it part of the third period exam?

(O5) Student 1: Professor, we have 8 days to solve the exam.

(O6) Professor 1: Yes, the idea is that in these 8 days, you explore the exam and then discuss it here in classes.

We can visualize in $(\mathrm{O} 1),(\mathrm{O} 2)$, and $(\mathrm{O} 6)$ that the professor uses the implementation of the exam as a tool to strengthen the evaluation of a certain period, where it serves as a support to invite the students to explore it since it is related to topics dealt with in the face-to-face classes, giving the possibility to develop that examination in a certain time.

\section{Situation 3}

In this situation we will present the teaching strategy called "Lessons Implementation", which consists of placing in a same section different assignments of the virtual platform where different tools are used, such as documents, videos, and links, among others. They are displayed by the student. It is important to emphasize that this teaching strategy was only used by professor 2 . Next, it shows one of the moments where this teaching strategy is used.

\section{Moment of Implementation-Professor 2}

(O1) Professor 2: [The professor creates lessons using different tools such as exam, documents, links, etc.]

(O2) Professor 2: In the virtual platform today we will work in Lesson 2. You must start with the exam and begin to develop the proposed assignments.

(O3) Student 1: Professor, should we do all the assignments that are in lesson 2?

(O4) Professor 2: Yes, the idea is for you to explore all the assignments in Lesson 2.

(O5) Student 2: And lesson 1, should we also do it?

(O6) Professor 2: Yes, if you want to review you can do it but the idea at this moment is to do lesson 2.

It is observed that in $(\mathrm{O} 1)$ and $(\mathrm{O} 2)$ professor 2 initially builds a lesson through different elements provided by the Chamilo platform and then share it with his students. Then, in (O4) and (O6) the professor invites the students to explore lesson 2 and also clarifies concerns that arise from their students.

\section{Situation 4}

In this situation we will show the teaching strategy called "Interactive Forum", which consisted of creating a space in the interaction platform where students can write their ideas and comments on a specific topic, helping 
the communication between students and the professor. In addition, it should be noted that this teaching strategy was used by the two professors as shown below:

\section{Moment of Implementation-Professor 1}

(O1) Professor 1: [Creates forum with topic on didactics of computer science]

(O2) Professor 1: I invite you to participate with your opinions on some of the questions asked: How would we teach computer science? What teaching elements would we use for teaching computer science? among others

(O3) Student 1: Professor, Should we answer all the questions within the forum or in a document and then we upload it?

(O4) Professor 1: Within the forum, there we will be able to interact among all, making contributions.

(O5) Student 2: Professor, should we participate with opinions about the opinions of other students?

(O6) Professor 1: That is the idea, but initially you participate with your opinions and after that you intervene at group level.

(O7) Students: Yes!

\section{Moment of Implementation-Professor 2}

(O8) Professor 2: [Design a forum referring to the English theme]

(O9) Professor 2: students, for today I will open the forum where each one of you must tell us about food that you like and a sport that you practice.

(O10) Student 1: Teacher, and if the person does not practice any sport?

(11) Professor 2: Then the one you like or you would like to practice.

(O12) Student 2: Teacher and if I do not like any sport?

(O13) Professor: At least the one you have to do ... [Laughs], such as walking, it is something we do frequently although sometimes we do not like it!

(O14) Student: Professor, in English?

(O15) Professor 2: Yes!

We have that, in $(\mathrm{O} 1)$ and $(\mathrm{O} 8)$ the professors start by opening the forum for students to participate with their opinions and ideas across different topics. In $(\mathrm{O} 2),(\mathrm{O} 4),(\mathrm{O} 6),(\mathrm{O} 9),(\mathrm{O} 11)$ and $(\mathrm{O} 13)$, the professors provide the different information so that students can manipulate this tool that helps them strengthen the dialogue between students and the professor by generating debates, discussion and feedback of knowledge among participants.

\section{Situation 5}

In this situation we will present the teaching strategy that we will call "virtual classroom exploration", which consisted in separating a virtual classroom, where a link is received to enter this virtual classroom. Then, the link is sent so students enter the date previously scheduled. The student must have audio and sound. It is important to emphasize that this teaching strategy was only used by professor 2. Next, one of the moments where this teaching strategy is used is shown.

\section{Moment of Implementation-Professor 2}

(O1) Professor 2: [Separate the virtual classroom in advance]

(O2) Professor 2: Students, I want to inform you that I already sent you the email with the link to use one of the virtual rooms. Did everyone receive it?

(O3) Students: Yes!

(O4) Student 1: Professor, can you explain how to attend it, should I come here to university?

(O5) Professor 2: Have you used virtual classrooms?

(O6) Student 2: Not much, just in the virtual courses offered by the faculty.

(O7) Professor 2: That's great! For those who have not done so, yesterday I sent an email where a link is found, 
did you read it?

(O8) Students: Yes.

(O9) Professor 2: Ok, Please open the link and you can confirm the time. It is important to remind you that you must have audio and sound. It is not necessary to come to the university if you have a computer or cell phone.

(O10) Student 2: Ok! Professor, I understand you, I must open the link. I have not do it.

(O11) Professor 2: Then I invite everyone to open the link, however, the virtual room is reserved for Tuesday at $7 \mathrm{pm}$. But I repeat, you must open it.

It is observed in (O1) that the professor separates in advance one of the virtual classrooms sending his students an email with the link that gives them the opportunity to enter the virtual classroom on the scheduled date. Then, in $(\mathrm{O} 2),(\mathrm{O} 5),(\mathrm{O} 7),(\mathrm{O} 9)$ and $(\mathrm{O} 11)$ the professor offers students different explanations; where he shows them elements that help them to strengthen the use of this tool.

Thus, the different strategies used by professors through the virtual educational platform Chamilo have been presented through the different situations. That is, we have five (5) situations where we represent five (5) teaching strategies with their respective implementation moment, which helps us visualize this element. Consequently, in the next section we will discuss the teaching strategies presented here.

\section{Discussion of the Data}

We will start this section by recalling the purpose of this article, which is to characterize the strategies used by professors through the use of the virtual educational platform Chamilo; through observation and interviews with the professors who participated in this study. The observation helped us to identify the teaching strategies, providing support to make and carry out the analysis, complemented with the interviews done to the professors as an integrated part of this research process.

In the situations presented in the previous section, we started by identifying the teaching strategy and then describing and discussing it. However, it is important to note that not all professors used the same teaching strategies.

In this sense, situation 1 presents the teaching strategy called "uploading documents and links", where the professor through a literature review, shares different documents with students, with the intention of inviting them to perform processes related to interpretation of reading and reflection. Thus, Glasserman, Monge, and Santiago (2014) in their study on teaching and learning experience with the Moodle platform, they implement this teaching strategy, resulting in the active participation of students in these spaces provided by that platform, and the correct way of using it becomes a challenge.

In situation 2, we find the teaching strategy "test implementation", which is closely related to the situation 3 "lesson implementation", although they seem to contain each other, the fact is that they are different. Anyway, it is important to highlight that both situations share common elements such as the documents located in different folders created by the professor, among others.

Fernández and Bermúdez (2009) use this type of teaching strategies, but they focus on the evaluation process rather than the exam or lesson; however, it is performed in an analogous way. The authors, through the evaluation, generate an integrated process to the development of certain topics where the student visualizes their academic progress through the evaluation carried out quarterly, showing the contents accessible to both professor and students through the face-to-face and virtual system, counting on the technical support which ensures access to materials and resources.

Next, in situation 4, we present the teaching strategy called "Interactive Forums" where the intentionality of the use of this tool is to generate the dialogue between classmates and the professor, by means of which they express their ideas, opinions, comments with the purpose of enriching the different themes treated in the classroom through the interaction and free use of expression in these spaces. Consequently, Ramírez (2015) argues that:

[...] Collaborative learning environments provide a series of tools for students to integrate into groups to interact and achieve assigned tasks. In this type of systems, students are free to express and communicate with each other, which can lead to problems of collaboration and communication that require the intervention of a professor.

Thus, Ramírez (2013) certainly bets on the interaction between students through the forums established by the professor, this greatly enriches the construction of knowledge. Consequently, Villota (2016) argues that students' interaction is a powerful tool when they develop their concepts, as it gives them the opportunity to share ideas 
and opinions, generating discussions and debates that undoubtedly help strengthen the students' learning process.

The teaching strategy called "virtual classroom exploration" is closely related to the use of virtual classrooms, which is an educational proposal that is related to face-to-face classes, being increasingly solid, broad and diversified in their use. Consequently, Barberà \& Badia (2005) argue that the use of virtual classrooms strengthens elements such as: 1 . less defined organization of educational space and time. 2. More extensive and intensive use of ICT. 3. Planning and organization of learning more guided in its global aspects. 4. Learning contents supported with a greater technological base. 5. Telematics ways of carrying out social interaction. 6 . Development of more student-centered learning activities.

\section{Conclusions}

The challenge of education is becoming more and more challenging, spaces and times are changing, the actors involved in the different training processes have increasingly pronounced variants. The integration of virtual platforms as a teaching and learning strategy becomes a very significant tool in all these processes.

This study characterizes the different strategies used by professors in the integration of the Chamilo virtual platform as a significant tool in academic training processes in an Education Faculty, evidencing a striking and motivating methodology towards the students.

The detailed analysis of each strategy allows visualizing the importance and relevance of the integration of virtual educational platforms in the teaching and learning processes for students, which are a further motivation for the good development of education training processes.

It was also possible to demonstrate the transformation to which these concepts of technological integration in face-to-face classes have led professors to a higher level in the integral management of tools, which strengthen their teaching processes, and definitely give a recognition to the professor as a leader of innovation in the classroom.

Consequently, it is important to highlight how the integration of the Chamilo virtual platform helps to generate different teaching strategies that strengthen pedagogical practice by broadening and inviting the professor to use these strategies, which mediate the curricular contents and the way to approach them with the student in the classroom, recognizing that the integration of ICT in the teaching and learning process, without a doubt, facilitates the learning process. In other words, it is fundamental that professors use variability of teaching strategies through virtual platforms, in order to help the students to appropriate the issues.

Finally, it should be emphasized that the implementation of the strategies characterized in this study, must be adjusted to the needs of the professor and therefore of the students, because the success of its use and utility depends on it. This permits reinforcement in the learning process of the students in order to generate meaningful learning in the course of the development of the different curricular contents.

\section{References}

Ardilla, M. (2011). Indicadores de calidad de las plataformas educativas digitales. Educ, 14(1), Recuperado de http://educacionyeducadores.unisabana.edu.co/index.php/eye/article/view/1836/2414

Angeli, C., \& Valanides, N. (2009). Epistemological and methodological issues for the conceptualization, development, and assessment of ICT-TPCK: Advances in technological pedagogical content knowledge (TPCK). Computers \& Education, 52(1), 154-168. https://doi.org/10.1016/j.compedu.2008.07.006

Barberà, E., \& Badia, A. (2005). Hacia el aula virtual: actividades y aprendizaje en la red. Revista Iberoamericana de Educación, 36(9). Disponible en: https://dialnet.unirioja.es/ejemplar/195119 1

Brodsky, M. (2003). Four blended learning blunders and how to avoid them. Learning circuits. En http//www.astd.org.

Brum-De-Paula, M. R., Espinar, y S. G. (2002). Coleta, transcrição e análise de produções orais. Letras, 1(21), $1-13$.

Bustillo, J., Rivera, C., Guzmán, J., \& Ramos, L. (2017). Benefits of using a mobile application in learning a foreign language. Sistemas \& Telemática, 15(40), 55-68.

Cebrián, M. (1976). Nuevas Competencias para la Formación Inicial y Permanente del Profesorado. EDUTEC 1997.

Díaz, S. (2009). Plataformas educativas, un entorno para profesores y alumnos. Federación de Enseñanza de C.C.O.O. de Andalucía. Plataformas virtuales. Disponible en http://www.youblisher.com/files/publications/7/37864/pdf.pdf 
Fernández, M., \& Bermúdez, M. (2009). La plataforma virtual como estrategia para mejorar el rendimiento escolar de los alumnos en la i.e.p Coronel José Joaquín Inclán de Piura. Revista Digital Sociedad de la Información http://www.sociedadelainformacion.com

Glasserman, L. D., Monge, P., \& Santiago, J. M. (2014). Experiencia de enseñanza-aprendizaje con la plataforma educativa abierta Moodle. Congreso Iberoamericano de Ciencia, Tecnología, Innovación y Educación, Buenos aires, Argentina. Disponible en: file://D:/Documentos\%20del\%20Sistema/Desktop/400.pdf

González, H. (2013). Let's work with technology. Cali, Colombia. Editorial Cadena.

González, H. (2015). La integración de la tecnología como herramienta significativa en la enseñanza del inglés como lengua extranjera. Revista Horizontes Pedagógicos, 17(1), 53-66.

Ministerio de Educación Nacional (2006). Educación: Visión 2019. Disponible en: http://www.mineducacion.gov.co/1621/article-122719.html

Nájar Sánchez, O., García Ávila, S., \& Grosso Molano, E. (2014). La plataforma virtual como herramienta didáctica dinamiza la lectura y la escritura. Revista Vínculos, 11(1), 189-202.

Pavón Babasco, F. (2005). Educación para las Nuevas Tecnologías. Pixel-Bit. Revista de Medios, 25, 1-10.

Pincas, A. (2003). Gradual and simple changes to incorporate ICT into the classroom. En Elearningeuropea.info.

Pico, M. J. S. (2004). Apuntes de estrategia sobre seguridad y defensa nacional. Universidad Militar Nueva Granada.

Ramírez, M. S. (2013). Modelos y estrategias de enseñanza para ambientes innovadores. Editorial Digital del Tecnológico de Monterrey.

Villota Enríquez, J. A. (2016). Estratégias utilizadas pelos professores que ensinam Matemáticas na implementação de tarefas. Tesis de maestria (Mestrado em Ensino, Filosofia e História das Ciências). Universidade Federal da Bahia/Universidade Estadual de Feira de Santana, Salvador de Bahia, Brasil.

Villota E. J., \& Riascos, F. Y. (2017). Estrategias utilizadas por profesores para fortalecer la seguridad de la información en una plataforma virtual: El caso de la plataforma educativa Chamilo. Memorias del 3er encuentro de investigadores de la RUAV. Cali, Colombia

\section{Copyrights}

Copyright for this article is retained by the author(s), with first publication rights granted to the journal.

This is an open-access article distributed under the terms and conditions of the Creative Commons Attribution license (http://creativecommons.org/licenses/by/4.0/). 